\title{
Gender Differences in Bank Loan Access: An Empirical Analysis
}

\author{
Giorgio Calcagnini · Germana Giombini • \\ Elisa Lenti
}

Received: 23 April 2013 / Accepted: 27 February 2014 / Published online: 12 December 2014 (C) Società Italiana degli Economisti (Italian Economic Association) 2014

\begin{abstract}
Traditionally, female entrepreneurs report either difficulties or higher costs in accessing bank credit. These problems can be either the result of supply-side discrimination, or differences in profitability between female- and male-owned firms. This paper aims at analysing whether these differences are statistically significant in the case of Italian firms by means of a large dataset on lines of credit provided by three Italian banks over the period 2005-2008. Descriptive statistics show that female-owned firms are significantly smaller and younger than male-owned ones, and have - on average - a larger, but shorter, number of lending relationships. Additionally, the mean size of loans requested by female-owned firms is smaller, and more frequently assisted with collateral, personal guarantees, or both. After controlling for loan, firm and bank characteristics, estimates show that gender does not affect the likelihood of obtaining a bank loan. However, in the case of female-owned firms, guarantees are less powerful instruments in gaining access to credit and the probability of having to pledge collateral is higher than for male-owned firms. Our findings suggest that differences in credit access are the result of discrimination and structural differences between male- and female-owned firms. Policies designed to improve the
\end{abstract}

We thank Rebel Cole, Jose Liberti, Geoffrey Hirth, Rosa Ferrer, and participants to the Stockholm EALE 2012 and to the Chicago MFA 2013, two anonymous referees, the editor Alberto Zazzaro, for useful comments and suggestions on the earlier version of this article. All remaining errors are ours.

G. Calcagnini · G. Giombini $(\bowtie)$ · E. Lenti

Department of Economics, Society, Politics, Università di Urbino, Via Saffi 42,

61029 Urbino, PU, Italy

e-mail: germana.giombini@uniurb.it

G. Calcagnini

e-mail: giorgio.calcagnini@uniurb.it

G. Calcagnini · G. Giombini

Mo. Fi. R., Ancona, Italy 
access of female-owned firms to bank loans should favor an increase in firm size that is often associated with the adoption of more sophisticated business legal structures.

Keywords Access to credit · Gender discrimination · Bank loan

JEL Classification $\quad \mathrm{E} 43 \cdot \mathrm{L} 26 \cdot \mathrm{G} 21 \cdot \mathrm{D} 82$

\section{Introduction}

In the last 25 years the number of female entrepreneurs has been growing significantly in Italy, and thus the peculiarities and difficulties related to business conducted by female entrepreneurs are of central interest to policy markers (Istat 2013). One of the most serious problems usually reported concerns the access to credit (Bianco et al. 2013), which is one of the key elements in firm life. In the event of financial constraints — credit rationing or, worse, a credit crunch-firms' ability to undertake new investment projects is seriously compromised, and their profit and growth opportunities are undermined. Therefore, a strand of the economic literature has been analysing whether gender differences in credit access and use of funds actually exist.

A large number of papers show the existence of gender differences in the composition of financial sources used by male- and female-owned firms. The latter are financially more fragile and face higher difficulties in accessing capital, whether in the form of equity or debt, than male-owned firms. Furthermore, female-owned firms make more intensive use of the entrepreneur's personal funds and a lower utilisation of bank loans (Carter and Shaw 2006; Coleman and Robb 2009). Moreover, other authors highlight that financial obstacles significantly explain why female-owned firms are smaller sized and have lower economic performance (lower profits and lower growth rates) than do male ones (Rosa et al. 1996; Fairlie and Robb 2009).

However, the same empirical findings do not provide us with a clear-cut explanation for gender differences, and three main and non-mutually-exclusive hypotheses can be addressed.

Briefly stated, gender differences in the use of funds may depend on: (i) structural differences between male- and female-owned firms, such as their size, date of foundation, credit history, owner age, and the type of industry (Coin 2011); (ii) demand side differences between female-owned and male-owned firms, such as owners' aversion to risk and willingness to loosen control (Bönte and Piegeler 2012); (iii) supply-side discrimination ${ }^{1}$.

According to Becker (1971), financial discrimination exists when banks apply higher interest rates on loans to female entrepreneurs, and these higher interest rates do not depend on lower credit worthiness, which is an assessment of the likelihood that a borrower will not default on its debt obligations. Credit worthiness is based on a borrower's credit history and structural characteristics (firm size, sector of activity, and the quality of its assets and liabilities). A lower acceptance rate or higher refusal rate in granting loans may also be a sign of gender discrimination (Storey 2004). What

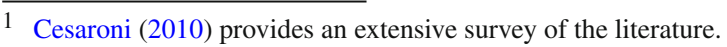


is more, banks could also discriminate by imposing heavier pre-contractual conditions on female-owned firms than on male-owned ones.

Empirically, Fay and Williams (1993) is one of the first studies that found some evidence of gender-related credit discrimination among start-ups. Muravyev et al. (2009) confirm this result by means of a cross-country analysis (Business Environment and Enterprise Performance Survey-BEEPS) which show that female-owned firms have a lower probability of obtaining a bank loan, and are charged higher interest rates than male-owned firms. Recently, using US data from the Survey of Small Business Finance-SSBF, Cole and Mehran (2011) show that female-owned firms are significantly more likely to be credit constrained because they are more likely to be discouraged from applying for credit and more likely to be denied credit when they do apply. However, these differences are rendered insignificant in a multivariate setting, where they control for other firm and owner characteristics. Their results indicate that gender-related disparity in credit market outcomes is not likely to be caused by taste-based discrimination. Using the same dataset, Asiedu et al. (2012) reach similar conclusions, as they find that White female firms did not face discrimination in terms of access to loans, and paid a lower interest rate than White male firms. In the same direction, Aterido et al. (2011) do not find evidence of a gender gap in the use of financial services by businesses and individuals in Sub-Saharan Africa.

Diversely, Ongena and Popov (2013) investigate a detailed dataset on 6,000 small business firms from 17 countries and find that in countries with higher gender bias, female-owned firms are more frequently discouraged from applying for bank credit and reliant on informal finance. Furthermore, their findings are not driven by credit risk differences between female- and male-owned firms in high-gender bias countries or by any idiosyncrasies in the set of countries in their sample.

As for Italy, Calcagnini and Lenti (2008) show that for a sample of Italian smallsized firms gender discrimination exists given that, ceteris paribus, female entrepreneurs are asked to pledge more guarantees that male entrepreneurs. Alesina et al. (2013) find that Italian female-owned firms are charged higher interest rates on their credit lines, while Bellucci et al. (2010) show that Italian female entrepreneurs face tighter credit availability, even though they do not pay higher interest rates. Recently, Cesaroni et al. (2013), using data from the Credit Register at the Bank of Italy for the period 2007-2009, found that female-owned firms faced more pronounced credit contraction with respect to other firms. Finally, Stefani and Vacca (2013) argue that female-owned firms apparently do experience tougher access to finance, but this evidence is almost completely explained by the fact that male- and female-owned firms are structurally different.

This paper contributes to the ongoing empirical debate by analysing gender differences in the bank loan access of Italian firms by means of a large dataset on loan applications provided by three Italian banks for the period 2005-2008. It improves on previous gender discrimination studies by following a broader approach that involves the joint analysis of gender differences in credit access and guarantee requirements. Specifically, the paper tests whether female- and male-owned firms have the same probability of obtaining a loan, after controlling for their respective credit worthiness by means of a set of firm, loan, and bank characteristics. Furthermore, it also tests whether female-owned businesses are subject to more stringent pre-contractual con- 
ditions in the form of heavier guarantee requirements than male-owned firms. To the best of our knowledge, this paper improves on existing literature by analyzing the impact of gender not only on collateral, but also on personal guarantees. Furthermore, banks in the sample identify female own firms both in the case of sole proprietorships and for corporations. In the latter case, banks adopted a narrow definition of female own firm according to the relative presence of women as partners or administrators.

Descriptive statistics show that female-owned firms are significantly smaller and younger than male-owned ones, and have — on average - a larger, but shorter, number of lending relationships. Additionally, the mean size of loans demanded by femaleowned firms is smaller, and more frequently assisted with collateral, personal guarantees, or both. After controlling for loan, firm and bank characteristics, estimates show that gender does not affect the likelihood of an applicant's obtaining a bank loan. However, in the case of female-owned firms, guarantees are less powerful instruments in gaining access to credit, and the probability of having to pledge collateral is higher than for male-owned firms. Our findings suggest that differences in credit access are the result of discrimination and structural differences between male- and female-owned firms. Policies designed to improve the access of female-owned firms to bank loans should favour an increase in firm size that is often associated with the adoption of more sophisticated business legal structures.

The paper is organized as follows. Section 2 describes the dataset used for model estimation. Section 3 presents the empirical models and the estimation strategy, and Sect. 4 discusses the main findings. Finally, Sect. 5 concludes.

\section{Data Description}

Data are provided by three Italian banks (Banca di Credito Cooperativo di Fano, San Paolo-Banca Popolare dell'Adriatico (BPDA), and the Banca di Credito Cooperativo di Cesena), and refer to new loan applications made by firms during the years 2005-2008².

Banks are located in the Italian provinces of Pesaro-Urbino, and Forlì-Cesena, as bank headquarters and most of their branches are active in those geographical areas. More than $50 \%$ of the available information comes from one banking source, i.e. the $\mathrm{BPDA}^{3}$.

The dataset contains 12,663 observations and each observation represents a loan application of one firm to one of the banks mentioned above. Even though bank branches are only located in two Italian provinces, the data are highly representative of the Italian economy in terms of gender distribution, productive structure, and industry composition.

Loan application information concerns whether the application was successful or rejected; the amount requested and the amount deliberated and, eventually, used; the type of loan [loans backed by accounts receivable, term-loans, revocable-loans, (Bank

\footnotetext{
2 The number of credit lines granted in 2008 is significantly lower than in the previous years of our sample.

3 Provincial market shares, calculated with respect to the number of bank branches, held by the three banks, are $17 \%$ for the Pesaro-Urbino province and $5 \%$ for the Forlì-Cesena province.
} 
of Italy 2010)]; the type of guarantee posted (collateral and/or personal guarantees), if any. Unfortunately, for reasons of privacy, banks did not provide data on interest rates.

Furthermore, information gathered on firm characteristics consisted in the type of company (sole proprietorship, partnerships, limited liability, public institutions, professional orders); the industry of activity; the provinces where firms are located; the distance (in kilometres) between each firm/loan and the headquarter of the bank that provides credit; the firm/entrepreneur age; firm total sales; the number of the lending relationships held by each firm and the length of those relationships.

Finally, the dataset contains information on "firm gender". Banks identify firms as "female-owned" or "male-owned" as follows. In the case of sole proprietorships female-owned businesses are obviously identified by the owner's gender. In all other cases, banks provided the identification of female-owned firms, according to the presence of women in the list of partners and administrators (see Table 11 in the Data Appendix).

\subsection{Firm Characteristics}

The dataset includes 4,365 firms, of which 1,293 (around $30 \%$ ) are female-owned firms. The total number of loan applications is 12,663 , of which 3,950 (31\%) were submitted by female-owned businesses (see Table 7).

The distribution of firms by gender in our dataset is consistent with that for the whole country: in Italy, in 2008, there were 1,429,267 female-owned firms, that is, $23 \%$ of the total number of firms. Similarly, the distribution of firms by legal type, size and industry in our sample and at the national level are broadly consistent with countrywide data (see Tables 8, 9, 10, Retecamere (2011) and Istat (2007)). Indeed, most of the firms in the dataset were set up as sole proprietorships (around $73 \%$ ), followed by partnerships $(15 \%)$ and limited liability companies $(9 \%)$. Professional orders and other business legal structures account for the remaining $3 \%$ (see Table 8). As for female-owned firms, $57 \%$ of them are organized as sole proprietorships, followed by partnerships and limited liability companies (31 and 10\%, respectively) (see Table 8). Moreover, the size distribution of firms by sales shows that about $90 \%$ of sample firms are micro-sized, i.e. their sales are below $€ 2,000,000$, and differences in firm size by gender are relatively small (Table 9). Finally, the distribution of firms by industry shows larger shares in the Wholesale and Retail Trade industry (relatively larger for female-owned firms), Manufacturing and Construction (relatively larger for male-owned firms) (Table 10). ${ }^{4}$

Table 1 provides summary statistics and t-tests for the variables used in the empirical analysis and shows that there are statistically significant structural differences between male- and female-owned firms. The latter are considerably smaller and younger than male-owned ones, and have — on average - a larger, but shorter term, number of lending relationships. However, female-owned firms appear to have a more sophisticated

\footnotetext{
4 This distribution is consistent with Italian data, according to which female firms are mainly concentrated in Commerce (32\%), and Agriculture (23\%), followed by Real Estate (10\%), Manufacturing (10\%) and Services $(9 \%)$. Furthermore, female-owned firms operating in the Commerce industry are usually the oldest ones (Retecamere (2011)).
} 
Table 1 Summary statistics: female-owned vs male-owned firms.

\begin{tabular}{|c|c|c|c|c|c|c|c|}
\hline \multirow{4}{*}{$\begin{array}{l}\text { Firms } \\
\text { Observations } \\
\text { Variables }\end{array}$} & \multirow{2}{*}{\multicolumn{2}{|c|}{$\begin{array}{l}\text { All firms } \\
4,365\end{array}$}} & \multirow{2}{*}{\multicolumn{2}{|c|}{$\begin{array}{l}\text { Female-owned firms } \\
1,293\end{array}$}} & \multirow{2}{*}{\multicolumn{2}{|c|}{$\begin{array}{l}\text { Male-owned firms } \\
3,072\end{array}$}} & \multirow[t]{3}{*}{ Means differences } \\
\hline & & & & & & & \\
\hline & \multicolumn{2}{|l|}{12,663} & \multicolumn{2}{|l|}{3,950} & \multicolumn{2}{|l|}{8,713} & \\
\hline & Mean & SD & Mean & $\mathrm{SD}$ & Mean & SD & $p$-values \\
\hline \multicolumn{8}{|l|}{ Dependent variable } \\
\hline Credit & 0.94 & $(0.23)$ & 0.95 & $(0.21)$ & 0.94 & $(0.24)$ & $0.000 * * *$ \\
\hline \multicolumn{8}{|l|}{ Loan characteristics } \\
\hline Loan size & 10.53 & (1.97) & 9.76 & $(2.69)$ & 10.88 & $(1.40)$ & $0.000 * * *$ \\
\hline Personal guarantees & 0.58 & $(0.49)$ & 0.65 & $(0.48)$ & 0.56 & $(0.50)$ & $0.000 * * *$ \\
\hline Collateral & 0.08 & $(0.27)$ & 0.16 & $(0.36)$ & 0.05 & $(0.21)$ & $0.000 * * *$ \\
\hline Guarantees and Collateral & 0.03 & $(0.18)$ & 0.11 & $(0.31)$ & 0.00 & $(0.00)$ & $0.000 * * *$ \\
\hline Unsecured loans & 0.37 & $(0.48)$ & 0.31 & $(0.01)$ & 0.40 & $(0.005)$ & $0.000 * * *$ \\
\hline \multicolumn{8}{|l|}{ Firm characteristics } \\
\hline Gender & 0.31 & $(0.46)$ & & & & & \\
\hline Sole proprietorship & 0.69 & $(0.46)$ & 0.54 & $(0.50)$ & 0.76 & $(0.43)$ & $0.000 * * *$ \\
\hline Partnership & 0.15 & $(0.35)$ & 0.29 & $(0.45)$ & 0.08 & $(0.28)$ & $0.000 * * *$ \\
\hline Limited liability & 0.12 & $(0.32)$ & 0.15 & $(0.36)$ & 0.10 & $(0.30)$ & $0.000 * * *$ \\
\hline Firm age & 48.03 & $(8.87)$ & 46.73 & (7.39) & 48.62 & $(9.40)$ & $0.000 * * *$ \\
\hline Firm size & 13.00 & $(2.06)$ & 12.77 & $(1.97)$ & 13.10 & $(2.08)$ & $0.000 * * *$ \\
\hline North-East & 0.26 & $(0.44)$ & 0.17 & $(0.38)$ & 0.30 & $(0.46)$ & $0.000 * * *$ \\
\hline North-West & 0.002 & $(0.05)$ & 0.00 & $(0.07)$ & 0.00 & $(0.03)$ & $0.000 * * *$ \\
\hline Central & 0.45 & $(0.50)$ & 0.61 & $(0.49)$ & 0.38 & $(0.48)$ & $0.000 * * *$ \\
\hline South & 0.28 & $(0.45)$ & 0.21 & $(0.41)$ & 0.32 & $(0.47)$ & $0.000 * * *$ \\
\hline Owner age & 45.64 & (8.09) & 44.44 & $(9.53)$ & 46.18 & $(7.27)$ & $0.000 * * *$ \\
\hline Multiple lending & 0.25 & $(0.24)$ & 0.29 & $(0.37)$ & 0.24 & $(0.15)$ & $0.000 * * *$ \\
\hline Relationship length & 1.35 & $(0.97)$ & 1.02 & $(0.92)$ & 1.50 & $(0.96)$ & $0.000 * * *$ \\
\hline
\end{tabular}

Source: Our calculations on data from the San Paolo-Banca Popolare dell'Adriatico, BCC Fano, BCC Cesena banks

business legal structures than male-owned ones, being more often organized in the form of partnerships or limited liability companies.

\subsection{Loan Characteristics}

The dataset collects all loan applications made to the three banks in the years 2005, 2006, 2007 and 2008. Bank evaluation of loan applications takes into account four possible outcomes: (a) loan is Deliberated (i.e., the loan has been granted and the application approved); (b) Refused (i.e., the application has been rejected); (c) Abandoned (i.e., the firm has abandoned the application); (d) Inquest (i.e., a firm loan application that the bank is still processing). When interviewed, bank managers explained that the Inquest outcome is often an informal way used by banks to refuse a loan. Thus, 
Table 2 Requested and granted amount of loan broken down by gender. Granted loans

\begin{tabular}{lccccc}
\hline Percentile & $10 \%$ & $25 \%$ & $50 \%$ & $75 \%$ & $90 \%$ \\
\hline Requested & & & & \\
Female-owned firms & 2,500 & 10,000 & 28,544 & 73,248 & 183,050 \\
Male-owned firms & 10,000 & 20,386 & 50,900 & 127,026 & 292,600 \\
Granted (as percentage of requested) & & & $68 \%$ & $68 \%$ \\
Female-owned firms & $100 \%$ & $80 \%$ & $71 \%$ & $65 \%$ & $96 \%$ \\
Male-owned firms & $50 \%$ & $50 \%$ & $50 \%$ & $602 \%$ \\
\hline
\end{tabular}

Source: our calculations on data from the San Paolo-Banca Popolare dell'Adriatico, BCC Fano, BCC Cesena banks

in our analysis, granted loans are the deliberated loan applications, while non-granted are the sum of refused, inquest, or abandoned loan applications.

Table 1 shows that the percentage distribution of female and male positive outcomes is statistically significant, notwithstanding the fact that the two percentages are similar: roughly 95 and $94 \%$ for female and male loan applications, respectively ${ }^{5}$.

The loan size (defined as the log of the amount of loan requested) is typically lower for female-owned firms (see Table 1). Furthermore, as concerns the distribution of the requested - and eventually granted-loan values (relative to the requested amount), it is worth noting that gender differences regard both variables (Table 2). In the first case, the value is substantially lower for female-owned firms at each shown percentile than male-owned firms (which likely reflects their relative firm size). In the second case, the amount of loan granted is higher for female-owned firms at each percentile, with the exception of the highest one. These findings seem to support the hypothesis that, ceteris paribus, smaller loans are considered by banks to be less risky, and thus have a higher likelihood of being granted.

Other gender differences emerge between secured and unsecured loans. Loans are either secured by collateral, by personal guarantees, or by both types of guarantees. Collateral consists in physical assets owned by the borrower or posted by a third party, while personal guarantees are contractual obligations of a third party and do not give the lender a specific claim on particular assets.

Personal guarantees are used more often than collateral to assist loans, and data show that male-owned firms have a higher percentage of unsecured loan applications than female-owned firms (40 and $31 \%$, respectively). The simultaneous presence of both types of guarantees happens only in the case of female-owned firms. All these gender differences are statistically significant as shown by the t-statistics reported in Table 1.

Section 3 discusses our empirical strategy to obtain a model specification that is able to describe the observed gender differences in variables associated with the credit access granted to Italian firms.

\footnotetext{
5 According to data from the Survey of Small Business Finance, in US the acceptance rate is about the $80 \%$ (Cole and Mehran 2011).
} 


\section{Model Specifications and Empirical Strategy}

This section aims at testing for the presence of gender differences in the access to bank credit by means of two empirical models.

The first is a probit model that is used to test if and how the probability of obtaining a successful loan application depends on firm gender and on loan-contract, individualfirm and -bank characteristics [respectively vectors F, L, and B in Eq. (1)] Furthermore, it includes a vector of control variables $(\mathrm{C})$, and time-dummy variables (T). The dependent variable "CREDIT" is a binary variable that takes a value equal to one if the loan has been granted and zero otherwise. The empirical equation takes the following form:

$\operatorname{Pr}(C R E D I T=1)_{i j t}=\Phi\left(\beta_{0}+\beta_{1}^{\prime} F_{i t}+\beta_{2}^{\prime} L_{i j t}+\beta_{3}^{\prime} B_{j}+\beta_{4}^{\prime} C_{i j t}+\beta_{5}^{\prime} T_{t}+\varepsilon_{i j t}\right)$

where $\Phi($.$) is the cumulative distribution function (cdf) of the standard normal distri-$ bution.

The second is a bivariate probit model that is used to test whether banks impose heavier pre-contractual conditions on female-owned firms than on male-owned ones. Specifically, it aims at understanding how entrepreneur gender influences the probability of observing secured loans together with firm, loan and bank characteristics (and other control variables). As guarantees are one of the components of the loan contracts, higher guarantee requirements could be interpreted as heavier contractual conditions. For instance, we expect that the variables that facilitate access to credit in Eq. (1), also reduce the probability of posting collateral and personal guarantees. A similar reasoning should hold for variables that impair bank credit access.

Theoretical models define guarantees as a mechanism to reduce equilibrium credit rationing and other problems that arise due to asymmetric information between borrowers and lenders. Specifically, in the presence of asymmetric information, guarantees play a role in solving problems that may arise at loan origination (hidden informationadverse selection) or after the loan has been granted (hidden action-moral hazard). These models suggest that guarantees may induce borrowers to identify themselves ex-ante (to solve adverse selection problem) and/or improve their incentives ex-post (to reduce moral hazard), potentially mitigating problems generated by the information gaps existing between borrowers and lenders (Berger and Udell 1990).

In Eqs. (2) and (3) we assume that collateral and personal guarantees are jointly determined and likely depend on the same set of variables:

$$
\begin{aligned}
\operatorname{Pr}(\text { Collateral }=1)_{i j t}= & \Phi\left(\gamma_{0}+\gamma_{1}^{\prime} F_{i t}+\gamma_{2}^{\prime} L_{i j t}+\gamma_{3}^{\prime} B_{j}\right. \\
& \left.+\gamma_{4}^{\prime} D_{i j t}+\gamma_{5}^{\prime} T_{t}+\eta_{i j t}\right)
\end{aligned}
$$

$$
\begin{aligned}
\operatorname{Pr}(\text { Personal Guarantees }=1)_{i j t}= & \Phi\left(\delta_{0}+\delta_{1}^{\prime} F_{i t}+\delta_{2}^{\prime} L_{i j t}+\delta_{3}^{\prime} B_{j}\right. \\
& \left.+\delta_{4}^{\prime} D_{i j t}+\delta_{5}^{\prime} T_{t}+v_{i j t}\right)
\end{aligned}
$$

As in Eq. (1) F, L, and B are vectors of firm, contract and bank characteristics. D is a vector of control variables, and (T) are time-dummies. Moreover, $\Phi($.$) is the cdf of$ the standard normal distribution. Variable definitions are shown in the data appendix. 


\subsection{Firm Characteristics and Expected Signs}

Vector F contains the following firm characteristics.

Gender is a dummy variable that takes a value equal to 1 for female firms and 0 for male firms. In the case of female discrimination in the bank loan market, the estimated coefficient of the dummy Gender should be statistically significant and negative in Eq. (1), but positive in Eqs. (2) and (3). This is the simplest case. However, when the Gender variable interacts with other firm or loan characteristics, gender discrimination could exist even if the gender coefficient is not statistically significant, but some of the coefficients of the interaction variables are.

Firm age is years from firm foundation. As older firms have had time to build up a reputation compared to younger firms, which therefore are considered riskier, informational opaqueness problems decrease (Berger and Udell 1998) with Firm age. Additionally, older firms have gained experience and survived under the threat of competition for a longer period. Thus, a positive estimated coefficient of the Firm age variable in Eq. (1) is expected. The same reasoning applies to Owner age, which measures the age of the entrepreneur or of the legally appointed Managing Director in the case of partnerships or corporations.

As for Eqs. (2) and (3), when guarantees are used to solve moral hazard problems, the probability of posting guarantees should be inversely related with Firm age and its coefficient negative (Jimènez et al. 2006).

Firm size is the logarithm of the total sales of the firm. Size plays an important role in firms' financial structure. Indeed, asymmetric information and informational opaqueness are generally more severe for small-sized firms than larger ones, and thus the former could turn out to be more financially constrained than the latter (Berger and Udell 1998). Therefore, a positive estimated coefficient of the Firm size variable in Eq. (1) is expected.

It is also expected that the probability of posting guarantees, when they are used to solve moral hazard problems, will be inversely related with the Firm size variable. Indeed, larger sized firms traditionally show stronger bargaining power and are considered typically less risky than smaller firms (Berger and Udell 1998).

The type of firm (sole proprietorship, partnership, limited liability) is controlled for by specific dummy variables. Berger and Udell (1998) show that partnership (Partnership) and limited liability companies (Limited liability) are considered less risky than sole proprietorships, as they suffer less from informational opaqueness. Therefore, the former are expected to enjoy better access to credit and a lower probability of having to pledge guarantees than the latter.

Equations (1), (2) and (3) include two controls for the number of loan applications submitted each year (Multilending), and for the length of the lending relationship (Relationship length). While the number of lending relationships is expected to have a negative impact on the probability of being financed in Eq. (1), it likely increases the probability of pledging guarantees in Eqs. (2) and (3), as multiple applications are a signal of difficulty in accessing credit and, therefore, of borrower risk (Pozzolo 2004). 
The impact of the length of the lending relationship (Relationship length) on the likelihood of obtaining a loan or posting guarantees is not defined a priori. The estimated coefficient of Relationship length in Eq. (1) is expected to be positive if it reduces asymmetric information problems, and negative if it generates hold-up problems. At the same time, a long-term banking relationship may benefit the borrowers by helping to build trust between borrowers and lenders, and consequently to reducing moral hazard (Boot and Thakor (1994), Berger and Udell (1995)). However, longer lending relationships could be associated with a higher use of collateral if long-term relationships generate more severe hold-up problems (Ogawa et al. (2010)).

Subsequently, we control for the sector of activity by means of the Sector dummies and for firm location by means of the Regional dummies (North-west, North-east, Central and South).

As we are controlling for a full set of firm characteristics that, in the absence of an explicit measure are proxies for firm risk, a statistically significant estimated coefficient of the Gender variable, or its interaction with the other firm characteristics, is a signal of discrimination in the bank loan market.

\subsection{Loan Characteristics and Expected Signs}

Vector L contains the characteristics of each loan contract.

Loan size is the log of the amount of loan requested by the firm from each bank in the database and proxies for the loan size. Larger loans, for a specified firm size, are typically riskier than smaller- sized ones. Therefore, in Eq. (1) the impact of Loan size is expected to be negative, because larger loans should be riskier than smaller sized ones (and, consequently, they have a negative impact on the probability of obtaining a loan). However, this variable is also a proxy for relative firm size, given that smallsized firms apply for smaller loans than larger-sized firms. In this case the impact of Loan size on the probability of obtaining a loan is positive. Similarly, in Eqs. (2) and (3) the probability of posting guarantees should increase with the loan size. However the expected sign could also be negative, as larger borrowers tend to be safer customers (Berger and Udell 1990).

Equation (1) makes use of additional information on the presence of guarantees to control for customers and loans risk. Specifically, the vector $L$ also includes three dummy variables, one for collateral (Collateral), one for personal guarantees (Personal guarantees), and a dummy (Guarantees and Collateral) to capture the simultaneous presence of both types of guarantee. These dummy variables also interact with the Gender variable to capture potential gender differences. The impact of guarantees on the probability of being financed is not defined a priori. On one hand, high quality borrowers may signal the bank by posting guarantees. Therefore, more guarantees increase the probability of loans being granted. On the other, if riskier borrowers are those who post more guarantees, their impact on the probability of being financed depends on whether guarantees fully compensate — or do not—-for borrower risk (Berger and Udell 1990). 
In Eqs. (2) and (3) we also control for the Loan type: loans backed by accounts receivable, term-loans, revocable-loans, bad debts and unpaid and protested own bills (Bank of Italy (2010)) ${ }^{6}$.

\subsection{Other Controls}

Vector B contains bank dummies to identify each bank in the sample: Bank1, Bank2 and Bank3 for Banca di Credito Cooperativo di Fano, San Paolo-Banca Popolare dell'Adriatico, and the Banca di Credito Cooperativo di Cesena, respectively.

\section{Result Discussion}

\subsection{The Impact of Gender on the Probability of Granted Loans}

This section discusses findings of different versions of model (1).

Table 3 shows estimated coefficients and marginal effects of two different specifications. Column (1) reports estimates from the baseline specification, in which the probability of successful loan application depends on gender and on loan characteristics, and bank, time and industry dummies. Findings suggest that there are gender differences in the access to credit, as the estimated coefficient and the marginal impact of Gender are both negative and statistically significant. However, once we control for a full set of firm characteristics, the Gender coefficient is no longer statistically significant as shown in Column (2) of Table (3). Estimates for the subsample of sole proprietorships confirm previous results as shown in columns (3) and (4) of Table 3: Gender does not appear to affect firm access to credit when we control for firm characteristics. This finding is in line with Cole and Mehran (2011), and Stefani and Vacca (2013) whose empirical analyses suggest that gender differences in access to credit are almost completely explained by male and female firms being structurally different (in terms of size, age, sector, proprietorship, on so on) ${ }^{7}$.

Indeed, estimates reported in columns (2) and (4) of Table 3 show that other variables affect the probability of a successful loan application. Among loan characteristics, Loan size reduces the probability of getting credit (i.e. a $1 \%$ increase in the amount of loan requested reduces the probability of obtaining credit of -1.23 and of $-1.30 \%$, in columns (2) and (4) respectively), while the presence of Collateral or Personal Guarantees increases firms' probability of obtaining a loan; the marginal effects of those variables (not tabulated) are equal to 11.30 and $9.90 \%$, in column (2) respectively ${ }^{8}$. Thus, guarantees are used as a mechanism to reduce equilibrium credit

\footnotetext{
6 Equations (2) and (3) do not include the Loan type variable, which is endogenous to the dependent dichotomous variable Credit.

7 For robustness check purposes, we dropped from the sample the observations for which the loan application outcome was "Inquest" and then we re-estimated model (1). Findings of columns (2) and (4) of Table (3) are confirmed. Estimates available upon request from the authors.

8 The marginal effects of Collateral and Personal guarantees are equal to 9 and $7.6 \%$ respectively, in column (4).
} 
rationing. However, the simultaneous presence of both types of guarantees reduces the probability of credit access, as the estimated coefficient of Guarantees and Collateral is negative and statistically significant, and its marginal effect is equal to $-16.78 \%$. In the dataset, only female-owned sole proprietorships post both types of guarantees. Thus, the estimated coefficient of Guarantees and Collateral suggests that banks consider female-owned firms to be riskier than male-owned ones, especially in the case of sole proprietorships.

While firms' legal type does not affect access to credit, older firms have a marginal advantage over younger ones: the estimated coefficient of Firm age in column (2) is positive and significant, and its marginal effect is $0.09 \%$, which corresponds to the increasing probability of obtaining a successful loan application if firm age increases by 1 . As expected, the number of lending relationships (Multiple lending) decreases the probability of being financed (i.e. if the number of lending relationships increases by 1 the probability of obtaining credit reduces of -6.20 and $7.41 \%$ in columns (2) and (4), respectively), while firms benefit from the length of the lending relationship (Relationship length), which increases firms' probability of gaining access to credit by 1.18 and $1.01 \%$ in columns (2) and (4), respectively.

Further, firm location matters, as firms from the South have a lower probability of being financed with respect to firms located in the North-East macro-region (the excluded dummy) $)^{9}$. Finally, loan applications made in 2008 show a lower probability of being successful with respect to those submitted in 2005, likely economic crisis and the credit crunch.

Table 4 shows the estimated coefficients of variables included in Eq. (1) augmented for interactions between the Gender variable and loan characteristics [columns (1) to (3)] and firm characteristics [columns (4) to (6)]. The aim of these models is to verify whether the role of the variables, whose coefficients in Table (3) are statistically significant, differs according to gender. As the magnitude of the interaction effect in nonlinear models does not equal the marginal effect of the interaction term, marginal effects of the interaction variables (not tabulated) are computed following $\mathrm{Ai}$ and Norton $(2003)^{10}$.

Column (1) in Table 4 focuses on guarantees. How does the marginal effect of collateral and personal guarantees change when Gender changes from 0 to 1 ?

First, in the case of female-owned firms, the coefficients of both interaction variables Collateral*Gender and Personal guarantees*Gender are negative. Marginal effects for these variables show that the presence of Collateral increases the probability to obtain credit of male- and female-owned firms by 12.5 and $8.5 \%$, respectively. The same probabilities for Personal guarantees are 11 and $7.3 \%$, respectively. Therefore, in the case of female-owned firms, collateral and personal guarantees seem less powerful instruments to obtain loans than for male-owned firms.

\footnotetext{
9 Differences in banking market concentration could account for observed differences in the availability of credit to female- and male-owned firms. Generally, the higher the level of competitiveness in the market, the lower the probability that banks will practice discrimination. The banking sector of the provinces of Pesaro and Urbino and Forlì-Cesena appears to be relatively more concentrated than other close financial markets (see Table 2.1 in Calcagnini and Lenti 2008).

10 We used the Stata 11 margins command to calculate the marginal effects of the interaction variables.
} 
Table 3 The impact of gender on credit access-Probit models.

\begin{tabular}{|c|c|c|c|c|}
\hline & \multicolumn{2}{|l|}{ Full sample } & \multicolumn{2}{|c|}{ Sole proprietorships } \\
\hline & (1) & (2) & (3) & (4) \\
\hline Intercept & $\begin{array}{l}2.201 * * * \\
(0.367)\end{array}$ & $\begin{array}{l}1.931 * * * \\
(0.423)\end{array}$ & $\begin{array}{l}3.313 * * * \\
(0.626)\end{array}$ & $\begin{array}{l}4.608^{* * *} \\
(0.725)\end{array}$ \\
\hline \multicolumn{5}{|l|}{ Loan characteristics } \\
\hline Loan size & $\begin{array}{l}-0.164 * * * \\
(0.031)\end{array}$ & $\begin{array}{l}-0.175^{* * *} \\
(0.026)\end{array}$ & $\begin{array}{l}-0.298 * * * \\
(0.029)\end{array}$ & $\begin{array}{l}-0.327 \text { *** } \\
(0.038)\end{array}$ \\
\hline Collateral & $\begin{array}{l}1.461 * * * \\
(0.195)\end{array}$ & $\begin{array}{l}1.611^{* * * *} \\
(0.217)\end{array}$ & $\begin{array}{l}1.812 * * * \\
(0.167)\end{array}$ & $\begin{array}{l}2.268 * * * \\
(0.178)\end{array}$ \\
\hline Personal guarantees & $\begin{array}{l}1.274 * * * \\
(0.234)\end{array}$ & $\begin{array}{l}1.413 * * * \\
(0.262)\end{array}$ & $\begin{array}{l}1.742 * * * \\
(0.444)\end{array}$ & $\begin{array}{l}1.899 * * * \\
(0.492)\end{array}$ \\
\hline Guarantees and Collateral & $\begin{array}{l}-2.801 * * * \\
(0.384)\end{array}$ & $\begin{array}{l}-2.393^{* * * *} \\
(0.318)\end{array}$ & & \\
\hline \multicolumn{5}{|l|}{ Firm characteristics } \\
\hline Gender & $\begin{array}{l}-0.075^{*} \\
(0.043)\end{array}$ & $\begin{array}{l}0.014 \\
(0.033)\end{array}$ & $\begin{array}{l}-0.210^{* * * *} \\
(0.035)\end{array}$ & $\begin{array}{l}-0.078 \\
(0.058)\end{array}$ \\
\hline Sole proprietorship & & $\begin{array}{l}0.056 \\
(0.144)\end{array}$ & & \\
\hline Partnership & & $\begin{array}{l}-0.207 \\
(0.164)\end{array}$ & & \\
\hline Firm age & & $\begin{array}{l}0.012 * * \\
(0.005)\end{array}$ & & $\begin{array}{l}0.009 \\
(0.007)\end{array}$ \\
\hline Firm size (log sales) & & $\begin{array}{l}0.004 \\
(0.013)\end{array}$ & & $\begin{array}{l}-0.031 \\
(0.024)\end{array}$ \\
\hline North west & & $\begin{array}{l}-0.107 \\
(0.359)\end{array}$ & & \\
\hline Central & & $\begin{array}{l}-0.179 \\
(0.269)\end{array}$ & & $\begin{array}{l}1.888 * * * \\
(0.524)\end{array}$ \\
\hline South & & $\begin{array}{l}-1.813^{* * * *} \\
(0.475)\end{array}$ & & $\begin{array}{l}-1.385^{\text {**** }} \\
(0.340)\end{array}$ \\
\hline Owner age & & $\begin{array}{l}0.001 \\
(0.003)\end{array}$ & & $\begin{array}{l}-0.005 \\
(0.003)\end{array}$ \\
\hline Relationship length & & $\begin{array}{l}0.168 * * * \\
(0.045)\end{array}$ & & $\begin{array}{l}0.254 * * * \\
(0.051)\end{array}$ \\
\hline Multilending & & $\begin{array}{l}-0.884 * * * \\
(0.141)\end{array}$ & & $\begin{array}{l}-1.864 * * * \\
(0.134)\end{array}$ \\
\hline \multicolumn{5}{|l|}{ Additional controls } \\
\hline Bank 1 dummy & $\begin{array}{l}0.800 * * * \\
(0.218)\end{array}$ & $\begin{array}{l}0.951 * * * \\
(0.310)\end{array}$ & $\begin{array}{l}1.478^{* *} \\
(0.576)\end{array}$ & $\begin{array}{l}-0.425 \\
(0.707)\end{array}$ \\
\hline
\end{tabular}


Table 3 continued

\begin{tabular}{|c|c|c|c|c|}
\hline & \multicolumn{2}{|l|}{ Full sample } & \multicolumn{2}{|c|}{ Sole proprietorships } \\
\hline & (1) & (2) & (3) & (4) \\
\hline \multirow[t]{2}{*}{ Bank 2 dummy } & $1.286^{* * *}$ & $2.634 * * *$ & $1.431 * * *$ & $2.468 * * *$ \\
\hline & $(0.316)$ & $(0.535)$ & $(0.406)$ & $(0.483)$ \\
\hline \multirow[t]{2}{*}{2006} & 0.172 & 0.031 & 0.721 & 0.392 \\
\hline & $(0.289)$ & $(0.230)$ & $(0.453)$ & $(0.347)$ \\
\hline \multirow[t]{2}{*}{2007} & 0.273 & 0.180 & 0.617 & 0.136 \\
\hline & $(0.262)$ & $(0.209)$ & $(0.473)$ & $(0.333)$ \\
\hline \multirow[t]{2}{*}{2008} & $-0.619 * * *$ & $-0.767 * * *$ & -0.568 & $-0.983 * * *$ \\
\hline & $(0.234)$ & $(0.186)$ & $(0.457)$ & $(0.266)$ \\
\hline Industry dummy & Yes & Yes & Yes & Yes \\
\hline Observations & 12,663 & 12,663 & 8,687 & 8,651 \\
\hline Pseudo R2 & 0.317 & 0.394 & 0.370 & 0.488 \\
\hline
\end{tabular}

Notes: This table reports the maximum likelihood estimates for the probit model (1) for firm access to credit. The Standard Errors are corrected for heteroskedasticity using Petersen (2009) two-dimensional clustering procedure. $* * * \mathrm{p}<0.01, * * \mathrm{p}<0.05, * \mathrm{p}<0.1$

Column (2) in Table 4 shows how the estimated marginal effect of Loan size changes when Gender changes from 0 to 1 . In this case, the impact of Loan size differs in magnitude according to gender, as the estimated coefficient of the interaction term Loan size* Gender is positive and statistically significant. The estimated coefficient corresponds to a marginal increasing probability effect of $0.57 \%{ }^{11}$. This finding suggests that the negative impact of the loan size is smaller in the case of femaleowned firms than for male-owned ones, and it also likely captures a firm size effect.

Column (3) of Table 4 shows the estimated coefficients of model (1) when we take into account the interaction of Gender with all loan characteristics, and estimates confirm the findings of columns (1) and (2). Furthermore, column (4) shows that older male-owned firms have better access to credit than female-owned ones. The estimated coefficient of Multilending*Gender shows that the existence of multiple lending relationships is less penalizing for female-owned firms than for male-owned ones (the marginal effect of the interaction term is $6.59 \%$ ), as shown in column (5) of Table 4. As for the length of the lending relationship [column (6)], the probability of credit access increases as long as the Relationship length increases, but its impact is the same for male- and female-owned firms.

Table 5 shows the estimates of the same models of Table 4 for the subsample of sole proprietorships. Differently from findings in Table 4, these results suggest that female-owned sole proprietorships have a lower probability of obtaining credit than male-owned ones. Specifically, the overall marginal effect of Gender turns out to be negative in columns (2) to (4) and (6) (it is, on average, $-0.3 \%$ ). This result suggests that, to improve access to bank loans, female-owned firms should pursue a strategy

\footnotetext{
11 See (Pinar Karaca et al. 2011) for a detailed analysis of marginal effects of interaction terms in nonlinear models.
} 


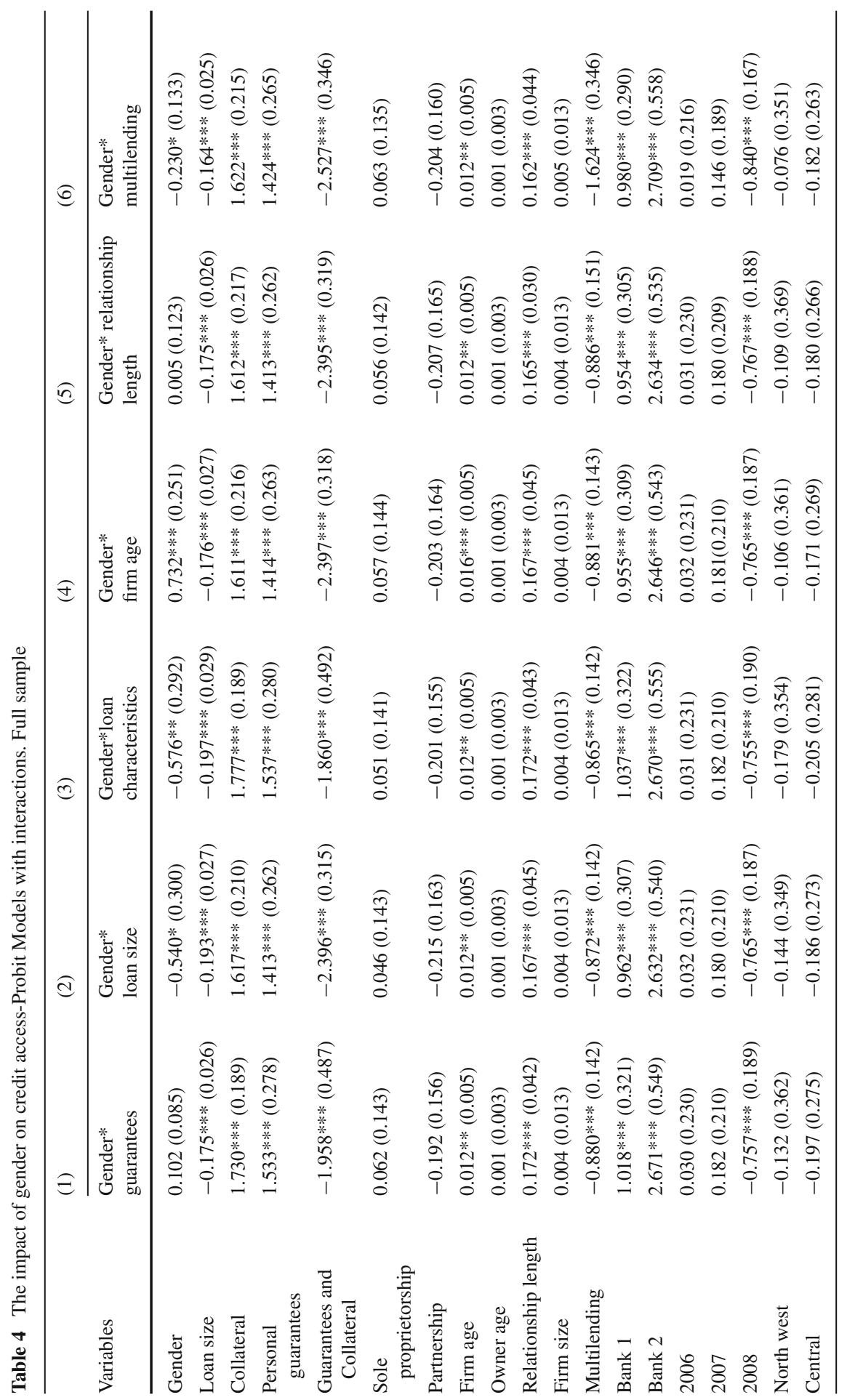




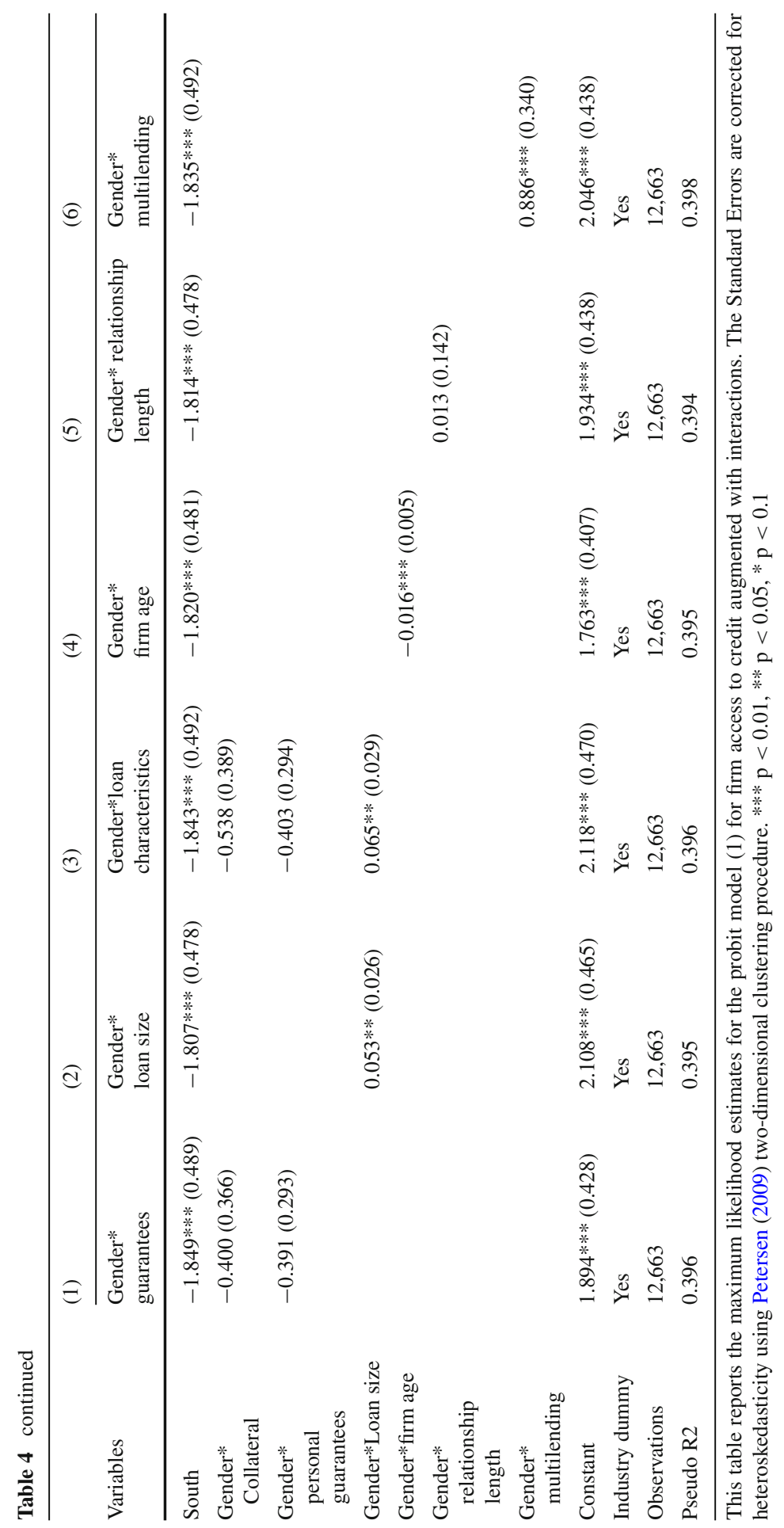


oriented towards increasingly adopting a more structured legal form such as that of partnerships or limited liability companies.

\subsection{The Impact of Gender on Personal Guarantees and Collateral}

The estimated Eq. (1) provides evidence that gender differences in credit access are especially linked to the role of guarantees in facilitating credit access.

To explore how gender interacts with guarantee requirements, in this section we test whether female-owned firms have a different probability of posting guarantees (personal or collateral) than male-owned ones. Unfortunately, we do not have loan pricing data, and the implications of the relation between gender and guarantees is therefore more problematic to identify, as we cannot disentangle: (i) whether the borrower was required to have a guarantee or (ii) whether the guarantee is a way to reduce the loan risk of the loan and this lower risk is reflected in the price. This second effect could be particularly important, given that some borrowers who have an outside personal guarantor may prefer to provide the bank third party guarantees in exchange for a lower interest rate (or contractual costs). What is more, women may have a lower risk tolerance and thus their preferences for the trade off between price and guarantees may differ from the preferences of men (Bönte and Piegeler 2012). However, Italian data on firm loans show that, on average, loans secured by personal guarantees are characterized by a higher price than unsecured loans, while loans secured by collateral have a lower interest rate (Calcagnini et al. 2014; Rodano et al. 2011).

Table 6, columns (1) and (2), shows the estimated coefficients of the bivariate probit model [Eqs. (2) and (3)], and the likelihood ratio test that rejects the null of zero correlation between the errors of the two probit models (see row labelled as LR test "rho =0") (Table 6).

Overall, the findings show that the probability of posting guarantees increases with the Loan size, which is consistent with the prediction that observably riskier borrowers are more likely to pledge collateral to solve moral hazard problems (Boot et al. 1991). However, the effect of loan size is smaller in the case of female-owned firms, as the estimated coefficient of the interaction term Loan size $e^{*}$ Gender is negative and statistically significant, and it also likely captures a firm-size effect as in Eq. (1) in Tables (3) and (4). Moreover, estimates show that female-owned firms are required to post relatively more collateral than male-owned ones, but relatively fewer third-party guarantees.

As expected, large firms (Firm size) have a lower probability of posting personal guarantees than do smaller firms. Among female-owned firms, increasing multiple loan applications (Multilending) positively affects the probability of posting collateral. Similarly, long-term lending relationships (Relationship length) between banks and customers positively affect the probability of posting both collateral and personal guarantees [column (1) ${ }^{12}$. The last findings suggest that the negative effects of the

\footnotetext{
12 Specifically if the firm is female-owned, a long-term lending relationship increases the probability of posting collateral, as the estimated coefficient of Relationship length *Gender is positive and statistically significant and more than counterbalances the negative estimated coefficient of Relationship length.
} 
Table 5 The impact of gender on credit access-Probit Models with interactions. Sole proprietorships

\begin{tabular}{|c|c|c|c|c|c|c|}
\hline & (1) & (2) & (3) & (4) & (5) & (6) \\
\hline Variables & $\begin{array}{l}\text { Gender* } \\
\text { guarantees }\end{array}$ & $\begin{array}{l}\text { Gender* } \\
\text { loan size }\end{array}$ & $\begin{array}{l}\text { Gender*loan } \\
\text { characteristics }\end{array}$ & $\begin{array}{l}\text { Gender* } \\
\text { firm age }\end{array}$ & $\begin{array}{l}\text { Gender* } \\
\text { relationship } \\
\text { length }\end{array}$ & $\begin{array}{l}\text { Gender* } \\
\text { multilending }\end{array}$ \\
\hline Gender & $\begin{array}{l}-0.068 \\
(0.085)\end{array}$ & $\begin{array}{l}-1.692 * * * \\
(0.400)\end{array}$ & $\begin{array}{l}-1.777 * * * \\
(0.423)\end{array}$ & $\begin{array}{l}1.107 * * * \\
(0.291)\end{array}$ & $\begin{array}{l}-0.435^{* * * *} \\
(0.061)\end{array}$ & $\begin{array}{l}-0.517 * * * \\
(0.140)\end{array}$ \\
\hline Loan size & $\begin{array}{l}-0.327 * * * \\
(0.038)\end{array}$ & $\begin{array}{l}-0.360 * * * \\
(0.040)\end{array}$ & $\begin{array}{l}-0.365^{* * * *} \\
(0.041)\end{array}$ & $\begin{array}{l}-0.331 * * * \\
(0.039)\end{array}$ & $\begin{array}{l}-0.332 * * * \\
(0.039)\end{array}$ & $\begin{array}{l}-0.325 * * * \\
(0.039)\end{array}$ \\
\hline Collateral & $\begin{array}{l}2.351 * * * \\
(0.362)\end{array}$ & $\begin{array}{l}2.252^{* * * *} \\
(0.170)\end{array}$ & $\begin{array}{l}2.427 * * * \\
(0.360)\end{array}$ & $\begin{array}{l}2.249 * * * \\
(0.174)\end{array}$ & $\begin{array}{l}2.316^{* * * *} \\
(0.195)\end{array}$ & $\begin{array}{l}2.201 * * * \\
(0.166)\end{array}$ \\
\hline $\begin{array}{l}\text { Personal } \\
\text { Guarantees }\end{array}$ & $\begin{array}{l}1.916 * * * \\
(0.573)\end{array}$ & $\begin{array}{l}1.921 * * * \\
(0.496)\end{array}$ & $\begin{array}{l}1.951 * * * \\
(0.582)\end{array}$ & $\begin{array}{l}1.910 * * * \\
(0.497)\end{array}$ & $\begin{array}{l}1.932 * * * \\
(0.496)\end{array}$ & $\begin{array}{l}1.918 * * * \\
(0.501)\end{array}$ \\
\hline Firm age & $\begin{array}{l}0.009 \\
(0.007)\end{array}$ & $\begin{array}{l}0.010 \\
(0.007)\end{array}$ & $\begin{array}{l}0.009 \\
(0.007)\end{array}$ & $\begin{array}{l}0.016 * * * \\
(0.006)\end{array}$ & $\begin{array}{l}0.010 \\
(0.006)\end{array}$ & $\begin{array}{l}0.009 \\
(0.007)\end{array}$ \\
\hline Owner age & $\begin{array}{l}-0.005 \\
(0.003)\end{array}$ & $\begin{array}{l}-0.004 \\
(0.003)\end{array}$ & $-0.004(0.003)$ & $\begin{array}{l}-0.005 \\
(0.003)\end{array}$ & $\begin{array}{l}-0.004 \\
(0.003)\end{array}$ & $\begin{array}{l}-0.004 \\
(0.003)\end{array}$ \\
\hline $\begin{array}{l}\text { Relationship } \\
\text { length }\end{array}$ & $\begin{array}{l}0.254 * * * \\
(0.051)\end{array}$ & $\begin{array}{l}0.251 * * * \\
(0.052)\end{array}$ & $\begin{array}{l}0.250 * * * \\
(0.053)\end{array}$ & $\begin{array}{l}0.246^{* * * *} \\
(0.054)\end{array}$ & $\begin{array}{l}0.163 * * \\
(0.064)\end{array}$ & $\begin{array}{l}0.246 * * * \\
(0.051)\end{array}$ \\
\hline Firm size & $\begin{array}{l}-0.031 \\
(0.023)\end{array}$ & $\begin{array}{l}-0.030 \\
(0.023)\end{array}$ & $-0.030(0.023)$ & $\begin{array}{l}-0.032 \\
(0.024)\end{array}$ & $\begin{array}{l}-0.033 \\
(0.025)\end{array}$ & $\begin{array}{l}-0.028 \\
(0.025)\end{array}$ \\
\hline Multilending & $\begin{array}{l}-1.859 * * * \\
(0.125)\end{array}$ & $\begin{array}{l}-1.881 * * * \\
(0.151)\end{array}$ & $\begin{array}{l}-1.868 * * * \\
(0.138)\end{array}$ & $\begin{array}{l}-1.888^{* * * *} \\
(0.147)\end{array}$ & $\begin{array}{l}-1.927^{* * * *} \\
(0.140)\end{array}$ & $\begin{array}{l}-2.223^{* * * *} \\
(0.173)\end{array}$ \\
\hline Bank 1 & $\begin{array}{l}-0.403 \\
(0.682)\end{array}$ & $\begin{array}{l}-0.475 \\
(0.727)\end{array}$ & $-0.439(0.700)$ & $\begin{array}{l}-0.458 \\
(0.725)\end{array}$ & $-0.123(0.720$ & $\begin{array}{r}-0.239 \\
(0.710)\end{array}$ \\
\hline Bank 2 & $\begin{array}{l}2.473 * * * \\
(0.490)\end{array}$ & $\begin{array}{l}2.384 * * * \\
(0.493)\end{array}$ & $\begin{array}{l}2.389 * * * \\
(0.495)\end{array}$ & $\begin{array}{l}2.517 * * * \\
(0.496)\end{array}$ & $\begin{array}{l}2.484 * * * \\
(0.492)\end{array}$ & $\begin{array}{l}2.419 * * * \\
(0.498)\end{array}$ \\
\hline 2006 & $\begin{array}{l}0.391 \\
(0.346)\end{array}$ & $\begin{array}{l}0.395 \\
(0.349)\end{array}$ & $\begin{array}{l}0.393 \\
(0.348)\end{array}$ & $\begin{array}{l}0.395 \\
(0.349)\end{array}$ & $\begin{array}{l}0.390 \\
(0.346)\end{array}$ & $\begin{array}{l}0.400 \\
(0.351)\end{array}$ \\
\hline 2007 & $\begin{array}{l}0.136 \\
(0.334)\end{array}$ & $\begin{array}{l}0.137 \\
(0.333)\end{array}$ & $\begin{array}{l}0.137 \\
(0.336)\end{array}$ & $\begin{array}{l}0.139 \\
(0.336)\end{array}$ & $\begin{array}{l}0.130 \\
(0.336)\end{array}$ & $\begin{array}{l}0.140 \\
(0.338)\end{array}$ \\
\hline 2008 & $\begin{array}{l}-0.985^{* * * *} \\
(0.269)\end{array}$ & $\begin{array}{l}-0.985^{* * * *} \\
(0.264)\end{array}$ & $\begin{array}{l}-0.990^{* * * *} \\
(0.267)\end{array}$ & $\begin{array}{l}-0.987 * * * \\
(0.263)\end{array}$ & $\begin{array}{l}-0.995^{* * * *} \\
(0.264)\end{array}$ & $\begin{array}{l}-1.009 * * * \\
(0.261)\end{array}$ \\
\hline Central & $\begin{array}{l}1.865^{* * * *} \\
(0.487)\end{array}$ & $\begin{array}{l}2.017 * * * \\
(0.556)\end{array}$ & $\begin{array}{l}1.986^{* * * *} \\
(0.509)\end{array}$ & $\begin{array}{l}1.941 * * * \\
(0.547)\end{array}$ & $\begin{array}{l}1.806^{* * * *} \\
(0.514)\end{array}$ & $\begin{array}{l}1.818 * * * \\
(0.577)\end{array}$ \\
\hline South & $\begin{array}{l}-1.388 * * * \\
(0.344)\end{array}$ & $\begin{array}{l}-1.307 * * * \\
(0.346)\end{array}$ & $\begin{array}{l}-1.308 * * * \\
(0.345)\end{array}$ & $\begin{array}{l}-1.411^{* * *} \\
(0.351)\end{array}$ & $\begin{array}{l}-1.395^{* * *} \\
(0.351)\end{array}$ & $\begin{array}{l}-1.339 * * * \\
(0.347)\end{array}$ \\
\hline $\begin{array}{l}\text { Gender* } \\
\text { Collateral }\end{array}$ & $\begin{array}{l}-0.240 \\
(0.473)\end{array}$ & & \multicolumn{2}{|l|}{$-0.560(0.468)$} & & \\
\hline \multirow[t]{2}{*}{$\begin{array}{l}\text { Gender* } \\
\text { personal } \\
\text { guarantees }\end{array}$} & -0.069 & & -0.117 & & & \\
\hline & $(0.338)$ & & $(0.357)$ & & & \\
\hline $\begin{array}{l}\text { Gender*loan } \\
\text { size }\end{array}$ & & $\begin{array}{l}0.154 * * * \\
(0.037)\end{array}$ & $\begin{array}{l}0.164 * * * \\
(0.041)\end{array}$ & & & \\
\hline
\end{tabular}


Table 5 continued

\begin{tabular}{|c|c|c|c|c|c|c|}
\hline & (1) & (2) & (3) & (4) & (5) & (6) \\
\hline Variables & $\begin{array}{l}\text { Gender* } \\
\text { guarantees }\end{array}$ & $\begin{array}{l}\text { Gender* } \\
\text { loan size }\end{array}$ & $\begin{array}{l}\text { Gender*loan } \\
\text { characteristics }\end{array}$ & $\begin{array}{l}\text { Gender* } \\
\text { firm age }\end{array}$ & $\begin{array}{l}\text { Gender* } \\
\text { relationship } \\
\text { length }\end{array}$ & $\begin{array}{l}\text { Gender* } \\
\text { multilending }\end{array}$ \\
\hline $\begin{array}{l}\text { Gender*firm } \\
\text { age }\end{array}$ & & & & $\begin{array}{l}-0.026 * * * \\
(0.007)\end{array}$ & & \\
\hline $\begin{array}{l}\text { Gender* } \\
\text { relationship } \\
\text { length }\end{array}$ & & & & & $\begin{array}{l}0.433 * * * \\
(0.069)\end{array}$ & \\
\hline $\begin{array}{l}\text { Gender* } \\
\text { multilending }\end{array}$ & & & & & & $\begin{array}{l}1.319 * * * \\
(0.299)\end{array}$ \\
\hline Constant & $\begin{array}{l}4.614 * * * \\
(0.725)\end{array}$ & $\begin{array}{l}4.867 * * * \\
(0.759)\end{array}$ & $\begin{array}{l}4.900 * * * \\
(0.763)\end{array}$ & $\begin{array}{l}4.333 * * * \\
(0.687)\end{array}$ & $\begin{array}{l}4.742 * * * \\
(0.768)\end{array}$ & $\begin{array}{l}4.594 * * * \\
(0.742)\end{array}$ \\
\hline $\begin{array}{l}\text { Industry } \\
\text { dummy }\end{array}$ & Yes & Yes & Yes & Yes & Yes & Yes \\
\hline Observations & 8,651 & 8,651 & 8,651 & 8,651 & 8,651 & 8,651 \\
\hline Pseudo R2 & 0.488 & 0.490 & 0.490 & 0.490 & 0.493 & 0.491 \\
\hline
\end{tabular}

This table reports the maximum likelihood estimates for the probit model (1) for firm access to credit augmented with interactions. The Standard Errors are corrected for heteroskedasticity using Petersen (2009) two-dimensional clustering procedure. $* * * \mathrm{p}<0.01$, $* * \mathrm{p}<0.05$, $* \mathrm{p}<0.1$

hold-up problem dominate the benefits of the lending relationship, especially in the case of female-owned firms: the strict behaviour of banks when dealing with female entrepreneurs does not improve over the course of the lending relationship. This finding clashes with the idea that women may be more likely to have a guarantor than men because female entrepreneurs do not have an established credit history.

\section{Conclusions}

This paper contributes to the research on the credit access of Italian firms by analysing the role of gender over the period 2005-2008. Our estimates show that gender does not affect the likelihood of obtaining a bank loan, after controlling for loan, firm and bank characteristics. However, in the case of female-owned firms, our analysis also shows that: (a) guarantees are less powerful instruments in gaining access to credit; (b) the probability of having to pledge collateral is higher than for male-owned firms. Furthermore, results show that the female-owned sole proprietorships' probability of obtaining a successful loan application is lower than that of male-owned ones. This result suggests that, to improve access to bank loans, female-owned firms should pursue a strategy oriented towards increasingly adopting a more structured legal form such as that of partnerships or limited liability companies.

Overall, findings suggest that disparities in credit market outcomes by gender are caused not only by discrimination, but also by structural differences between maleand female-owned firms. 
Table 6 The impact of gender on guarantees-Bivariate probit model

\begin{tabular}{|c|c|c|c|c|c|c|}
\hline & \multicolumn{3}{|l|}{ Collateral } & \multicolumn{3}{|c|}{ Personal Guarantees } \\
\hline & $\begin{array}{l}\text { Coefficient } \\
\text { value }\end{array}$ & $\begin{array}{l}\text { Standard } \\
\text { error }\end{array}$ & $\begin{array}{l}\text { Marginal } \\
\text { impact \% }\end{array}$ & $\begin{array}{l}\text { Coefficient } \\
\text { value }\end{array}$ & $\begin{array}{l}\text { Standard } \\
\text { error }\end{array}$ & $\begin{array}{l}\text { Marginal } \\
\text { impact \% }\end{array}$ \\
\hline Intercept & $-3.973 * * *$ & $(0.422)$ & & -0.111 & $(0.221)$ & \\
\hline \multicolumn{7}{|l|}{ Loan characteristics } \\
\hline Loan size & $0.269 * * *$ & $(0.047)$ & 1.72 & $0.105 * * *$ & $(0.036)$ & 2.40 \\
\hline Gender*Loan size & $-0.236 * * *$ & $(0.047)$ & -1.60 & $-0.127 * * *$ & $(0.035)$ & -6.14 \\
\hline \multicolumn{7}{|l|}{ Firm Characteristics } \\
\hline Gender & $2.611 * * *$ & $(0.527)$ & 1.66 & $0.969 *$ & $(0.529)$ & -1.96 \\
\hline Sole proprietorship & -0.096 & $(0.127)$ & $-1.13 \%$ & 0.109 & $(0.111)$ & 3.85 \\
\hline Partnership & -0.028 & $(0.062)$ & -0.33 & $0.639 * * *$ & $(0.063)$ & 22.48 \\
\hline Firm age & -0.003 & $(0.005)$ & -0.08 & 0.001 & $(0.004)$ & 0.07 \\
\hline Gender*Firm age & -0.007 & $(0.006)$ & -0.17 & 0.004 & $(0.005)$ & 0.13 \\
\hline $\begin{array}{l}\text { Firm size } \\
\text { (sales log) }\end{array}$ & 0.015 & $(0.018)$ & 0.19 & $-0.056 * * *$ & $(0.008)$ & -1.98 \\
\hline North-west & $0.796 * * *$ & $(0.151)$ & 9.41 & 0.420 & $(0.441)$ & 14.75 \\
\hline Central & -0.013 & $(0.134)$ & -0.15 & 0.246 & $(0.090)$ & 8.64 \\
\hline South & -0.092 & $(0.221)$ & 1.09 & $0.381 * * *$ & $(0.111)$ & 13.38 \\
\hline Multilending & 0.119 & $(0.103)$ & 4.62 & 0.250 & $(0.251)$ & 12.57 \\
\hline $\begin{array}{l}\text { Gender* } \\
\text { Multilending }\end{array}$ & $0.523 * * *$ & $(0.122)$ & 11.53 & 0.370 & $(0.336)$ & 10.97 \\
\hline Owner age & -0.002 & $(0.002)$ & -0.002 & $-0.008 * * *$ & $(0.003)$ & -0.27 \\
\hline Relationship length & $-0.141 * *$ & $(0.060)$ & -0.26 & $0.178 * * *$ & $(0.060)$ & 6.49 \\
\hline $\begin{array}{l}\text { Gender* } \\
\text { Relationship } \\
\text { length }\end{array}$ & $0.228 * *$ & $(0.095)$ & 2.86 & 0.023 & $(0.033)$ & 0.05 \\
\hline \multicolumn{7}{|l|}{ Addidtional controls } \\
\hline Bank 1 & $1.079 * * *$ & $(0.267)$ & 12.74 & $0.810 * * *$ & $(0.144)$ & 28.45 \\
\hline Bank 2 & 0.062 & $(0.243)$ & 0.74 & $-0.384 * * *$ & $(0.098)$ & -13.50 \\
\hline 2006 & $-0.120 * *$ & $(0.050)$ & -1.42 & -0.050 & $(0.075)$ & -1.76 \\
\hline 2007 & -0.086 & $(0.074)$ & -1.02 & -0.056 & $(0.063)$ & -1.96 \\
\hline 2008 & $0.512 * * *$ & $(0.135)$ & 6.05 & $-0.182 * *$ & $(0.078)$ & -6.38 \\
\hline Industry dummies & Yes & & & Yes & & \\
\hline Loan type dummies & s Yes & & & Yes & & \\
\hline Observations & 11,972 & & & 11,972 & & \\
\hline $\begin{array}{l}\mathrm{LR} \text { test "rho = } \\
0 "(\mathrm{p} \text { value })\end{array}$ & 0.002 & & & & & \\
\hline
\end{tabular}

This table reports the maximum likelihood estimates for the bivariate probit Eqs. (2) and (3) for the probability that firms will post guarantees. Marginal effects of the interaction variables are calculated following Ai and Norton (2003). The Standard Errors of estimated coefficients are corrected for heteroskedasticity using the two-dimensional clustering procedure of Petersen (2009). The standard error of the marginal effects (not tabulated) is calculated at the means of the explanatory variables using the delta method (Greene 2008, pp. 68-70). *** p $<0.01$, ** $\mathrm{p}<0.05, * \mathrm{p}<0.1$ 


\section{Appendix: Data}

See Tables 7, 8, 9, 10, 11 .

Table 7 Dataset composition by gender: absolute values and percentage distribution

\begin{tabular}{llcrr}
\hline Gender & Number of firms & $\%$ & Number of loan applications & $\%$ \\
\hline Female-owned firm & 1,293 & 29.62 & 3,950 & 31.19 \\
Male-owned firm & 3,072 & 70.38 & 8,713 & 68.81 \\
Total & 4,365 & 100.00 & 12,663 & 100.00 \\
\hline
\end{tabular}

Source: our calculations on data from the San Paolo-Banca Popolare dell'Adriatico, BCC Fano, and BCC Cesena banks

Table 8 Distribution of firms by legal type: absolute values and percentage distribution (between parentheses)

\begin{tabular}{lcccc}
\hline Legal type & $\begin{array}{l}\text { Female-owned } \\
\text { firms }\end{array}$ & Male-owned firms & Total & $\begin{array}{l}\text { Female-owned firms: } \\
\text { countrywide data (2008) }\end{array}$ \\
\hline Sole proprietorship & $735(56.84)$ & $2,472(80.47)$ & $3,207(73.47)$ & $872,969(61.1)$ \\
Partnership & $396(30.63)$ & $265(8.63)$ & $661(15.14)$ & $323,862(22.7)$ \\
Limited liability & $133(10.29)$ & $239(7.78)$ & $372(8.52)$ & $200,638(14.0)$ \\
Professional orders & $25(1.93)$ & $96(3.12)$ & $121(2.77)$ & \\
Other & $4(0.31)$ & $0(0.00)$ & $4(0.09)$ & $31,798(2.3)$ \\
Total & $1,293(100.00)$ & $3,072(100.00)$ & $4,365(100.00)$ & $1,429,267(100.00)$
\end{tabular}

Source: our calculations on data from the San Paolo-Banca Popolare dell'Adriatico, BCC Fano, BCC Cesena banks

Table 9 Firm size by gender: absolute values and percentage distribution (between parentheses)

\begin{tabular}{lrcrcrl}
\hline Firm size & \multicolumn{2}{l}{ Female-owned firms } & \multicolumn{2}{l}{ Male-owned firms } & \multicolumn{2}{l}{ Total } \\
\hline Big enterprise & 45 & $(3.48)$ & 191 & $(6.22)$ & 236 & $(5.41)$ \\
Medium enterprise & 72 & $(5.57)$ & 227 & $(7.39)$ & 299 & $(6.85)$ \\
Small enterprise & 24 & $(1.86)$ & 85 & $(2.77)$ & 109 & $(2.5)$ \\
Micro enterprise & 1,152 & $(89.1)$ & 2,569 & $(83.63)$ & 3,721 & $(85.25)$ \\
Total & 1,293 & $(100)$ & 3,072 & $(100)$ & 4,365 & $(100)$ \\
\hline
\end{tabular}

We use total sales data to define firm size according to the EU Commission definition (GUCE L 124/36 del 20/05/2003). Big enterprises: have at least 250 employees, their annual turnover is equal or greater than 50 million EUR, or their balance sheet total is greater than 43 million EUR; Medium enterprises: have between 50 and 249 employees. They should have an annual turnover not exceeding 50 million EUR or an annual balance-sheet total not exceeding 43 million EUR; Small enterprises: have between 10 and 49 employees. They should have an annual turnover not exceeding 10 million EUR or an annual balance-sheet total not exceeding 10 million EUR; Micro enterprises : have fewer than 10 employees, their annual turnover or their annual balance sheet total assets should not exceed 2 million EUR.

Source: our calculations on data from the San Paolo-Banca Popolare dell'Adriatico, BCC Fano, and BCC Cesena banks 
Table 10 Distribution of firms by sector of economic activity, ATECO 2007: absolute values and percentage distribution (between parentheses)

\begin{tabular}{|c|c|c|c|}
\hline Sector of activity & Female-owned firms & Male-owned firms & Total firms \\
\hline Agriculture, forestry, fishing and hunting & $74(5.72)$ & $261(8.5)$ & 335 (7.67) \\
\hline Manufacturing & $270(20.88)$ & $598(19.47)$ & $868(19.89)$ \\
\hline Electricity, gas, steam and hot water supply & $0(0.00)$ & $8(0.26)$ & $8(0.18)$ \\
\hline $\begin{array}{l}\text { Collection, purification and } \\
\text { distribution of water; waste } \\
\text { management }\end{array}$ & $5(0.39)$ & $15(0.49)$ & $20(0.46)$ \\
\hline Construction & $47(3.63)$ & $468(15.23)$ & $515(11.8)$ \\
\hline $\begin{array}{l}\text { Wholesale and retail trade, } \\
\text { repair of motor vehicles }\end{array}$ & $380(29.39)$ & $607(19.76)$ & $987(22.61)$ \\
\hline Transportation and warehousing & $17(1.31)$ & $229(7.45)$ & $246(5.64)$ \\
\hline Accommodation and food services & $140(10.83)$ & $158(5.14)$ & $298(6.83)$ \\
\hline Finance and insurance & $138(10.67)$ & $387(12.6)$ & $525(12.03)$ \\
\hline Real estate activities & $13(1.01)$ & $9(0.29)$ & $22(0.5)$ \\
\hline $\begin{array}{l}\text { Professional, scientific, and } \\
\text { technical services }\end{array}$ & $14(1.08)$ & $81(2.64)$ & $95(2.18)$ \\
\hline $\begin{array}{l}\text { Rental, travel agencies, and } \\
\text { support services to firms }\end{array}$ & $4(0.31)$ & $14(0.46)$ & $18(0.41)$ \\
\hline Public administration & $7(0.54)$ & $23(0.75)$ & $30(0.69)$ \\
\hline $\begin{array}{l}\text { Other services (except Public } \\
\text { Administration) }\end{array}$ & $160(12.37)$ & $174(5.66)$ & $334(7.65)$ \\
\hline Total & $1,293(100.00)$ & $3,072(100)$ & $4,365(100)$ \\
\hline
\end{tabular}

Source: our calculations on data from the San Paolo-Banca Popolare dell'Adriatico, BCC Fano, and BCC Cesena banks

Table 11 List of variables

\begin{tabular}{ll}
\hline Variable & Definition \\
\hline & A dichotomous variable that takes the value of 1 if the firm is \\
& female-owned, and 0 otherwise. In the case of sole proprietorships, \\
& female-owned businesses are identified by the owner's gender. In all \\
& other cases, banks provided the identification of female-owned firm \\
& if the presence of women among partners and administrators is at \\
& least the "majority" according to the following table: \\
\hline
\end{tabular}


Table 11 continued

\begin{tabular}{|c|c|c|c|}
\hline Variable & Presence of women & Limited liability & $\begin{array}{l}\text { Partnerships and } \\
\text { other juridical type }\end{array}$ \\
\hline & Majority & $\begin{array}{l}\text { If in the list of } \\
\text { partners women hold } \\
\text { more than } 50 \% \text { of } \\
\text { social capital and } \\
\text { women are more } \\
\text { than } 50 \% \text { of total } \\
\text { "administrators" } \\
\text { If the list of partners } \\
\text { is not available at the } \\
\text { registry of firms: } \\
\text { women are more } \\
\text { than } 50 \% \text { of total } \\
\text { "administrators" }\end{array}$ & $\begin{array}{l}>50 \% \text { "partners" or } \\
>50 \% \text { "administrators" }\end{array}$ \\
\hline \multirow[t]{3}{*}{ Gender } & $\begin{array}{l}\text { Strong (see the } \\
\text { 215/92 Italian Law) }\end{array}$ & If in the list of & $>60 \%$ "partners" or \\
\hline & & $\begin{array}{l}\text { partners women hold more than } 2 / 3 \\
\text { of social capital and women } \\
\text { are more than } 2 / 3 \text { of total "administrators" } \\
\text { If the list of partners } \\
\text { is not available at the } \\
\text { registry of firms: } \\
\text { women are more } \\
\text { than } 2 / 3 \text { of total } \\
\text { "administrators" }\end{array}$ & $>60 \%$ "administrators" \\
\hline & Exclusive & $\begin{array}{l}\text { If in the list of } \\
\text { partners women hold } \\
\text { more than } 100 \% \text { of } \\
\text { social capital and } \\
\text { women are more } \\
\text { than } 100 \% \text { of total } \\
\text { "administrators" } \\
\text { If the list of partners } \\
\text { is not available at the } \\
\text { registry of firms: } \\
\text { women are more } \\
\text { than } 100 \% \text { of total } \\
\text { "administrators" }\end{array}$ & $\begin{array}{l}100 \% \text { "partners" or } \\
100 \% \text { "administrator" }\end{array}$ \\
\hline
\end{tabular}


Table 11 continued

\begin{tabular}{|c|c|}
\hline Variable & Definition \\
\hline Loan size & The logarithm of the amount of loan requested. \\
\hline Personal guarantees & $\begin{array}{l}\text { A dichotomous variable that takes the value of } 1 \text { if the borrower's } \\
\text { loan is assisted by personal guarantees, and } 0 \text { otherwise. }\end{array}$ \\
\hline Collateral & $\begin{array}{l}\text { A dichotomous variable that takes the value of } 1 \text { if the borrower's } \\
\text { loan is collateralised, and } 0 \text { otherwise. }\end{array}$ \\
\hline Sole Proprietorship & $\begin{array}{l}\text { A dichotomous variable that takes the value of } 1 \text { if the firm is a sole } \\
\text { proprietorship, and } 0 \text { otherwise. }\end{array}$ \\
\hline Partnership & $\begin{array}{l}\text { A dichotomous variable that takes the value of } 1 \text { if the firm is a } \\
\text { partnership, and } 0 \text { otherwise. }\end{array}$ \\
\hline Limited liability & $\begin{array}{l}\text { A dichotomous variable that takes the value of } 1 \text { if the firm is a } \\
\text { limited liability company, and } 0 \text { otherwise. }\end{array}$ \\
\hline Firm age & Years from firm foundation. \\
\hline Firm size & The log of the total sales of the firm. \\
\hline North-East & $\begin{array}{l}\text { A dichotomous variable that takes the value of } 1 \text { if the firm is located } \\
\text { in the North-east, and } 0 \text { otherwise. }\end{array}$ \\
\hline North-West & $\begin{array}{l}\text { A dichotomous variable that takes the value of } 1 \text { if the firm is located } \\
\text { in the North-west, and } 0 \text { otherwise. }\end{array}$ \\
\hline Central & $\begin{array}{l}\text { A dichotomous variable that takes the value of } 1 \text { if the firm is located } \\
\text { in the Central, and } 0 \text { otherwise. }\end{array}$ \\
\hline South & $\begin{array}{l}\text { A dichotomous variable that takes the value of } 1 \text { if the firm is located } \\
\text { in the South, and } 0 \text { otherwise. }\end{array}$ \\
\hline Owner age & Age of the firm owner. \\
\hline Multiple Lending & Number of loan applications submitted by the firm each year. \\
\hline Relationship Length & $\begin{array}{l}\text { The length of the bank-borrower relationship expressed in years, } \\
\text { divided by } 10 \text {. }\end{array}$ \\
\hline
\end{tabular}

\section{References}

Ai C, Norton EC (2003) Interaction terms in logit and probit models. Econ Lett 80:123-129

Alesina A, Lotti F, Mistrulli P (2013) Do women pay more for credit? Evidence from Italy. J Eur Econ Assoc 11:45-66. doi:10.1111/j.1542-4774.2012.01100.x

Aterido R, Beck T, Iacovone L (2011) Gender and finance in Sub-Saharan Africa: Are women disadvantaged? World Bank Policy Research Working Paper 5571

Asiedu E, Freeman J (2012) Access to credit by small businesses: How relevant are race, ethnicity, and gender? Am Econ Rev 102:532-537

Bank of Italy (2010) Statistical Bulletin 4/2010

Becker GS (1971) The economics of discrimination. University of Chicago Press Chicago, IL

Bellucci A, Borisov AV (2010) Does gender matter in bank-firm relationships? J Bank Finance 34(12):29682984

Berger AN, Udell GF (1990) Collateral, loan quality, and bank risk. J Monet Econ 25:21-42

Berger AN, Udell GF (1995) Relationship lending and lines of credit in small firms finance. J Bus 68(3):351381

Berger AN, Udell GF (1998) The economics of small business finance: the roles of private equity and debt markets in the financial growth cycle. J Bank Finance 22:613-673 
Bianco M, Lotti F, Zizza R (2013) Le donne e l'economia Italiana. Banca d'Italia, n, Questioni di Economia e Finanza, p 171

Bönte W, Piegeler M (2012) Gender gap in latent and nascent entrepreneurship: driven by competitiveness. Small Bus Econ. doi:10.1007/s11187-012-9459-3

Boot AWA, Thakor AV (1994) Moral hazard and secured lending in an infinitely repeated credit market game. Int Econ Rev 35(4):899-920

Boot AWA, Thakor AV, Udell GF (1991) Secured lending and default risk: equilibrium analysis, policy implications, and empirical results. Econ J 101(406):458-472

Calcagnini G, Lenti E (2008) Discriminazione nell'accesso al credito per l'imprenditoria femminile. In: I vincoli finanziari alla crescita delle imprese, a cura di A. Zazzaro, Roma, Carocci Editore, pp 45-61

Calcagnini G, Farabullini F, Giombini G (2014) The impact of guarantees on bank loan interest rates. Appl Financ Econ 6:397-412

Carter S, Shaw E (2006) Women's Business Ownership: Recent Research and Policy Developments, Report to the Small Business Service, November

Cesaroni F (2010) Donne Imprenditrici e Banche. Le Ragioni di un Rapporto Difficile. In: Calcagnini G, Favaretto I (eds.) LEconomia della Piccola Impresa, pp 131-167. FrancoAngeli: Milano

Cesaroni F, Lotti F, Mistrulli PE (2013) Female firms and banks' lending behavior: what Happened During the Great Recession? Banca d'Italia, n, Questioni di Economia e Finanza, p 177

Coin D (2011) Are Women Entrepreneurs better Payers than Men? Bank of Italy research paper

Cole RA, Mehran H (2011) Gender and the Availability of Credit to Privately Held Firms: Evidence from the Surveys of Small Business Finances. FRB of New York Staff Report No. 383. Available at SSRN: http://ssrn.com/abstract=1799649 or http://dx.doi.org/10.2139/ssrn.1799649

Coleman S, Robb A (2009) A comparison of new firm financing by gender: evidence form the Kauffman Firm Survey Data. Small Bus Econ 33:397-411

Fairlie R, Robb A (2009) Gender differences in business performance: evidence from the Characteristics of Business Owner Survey. Small Bus Econ 33:375-395

Fay M, Williams L (1993) Gender bias and the availability of business loans. J Bus Ventur 8(4):363-376. doi:10.1016/0883-9026(93)90005-P

Greene WH (2008) Econometric analysis, 6th edn. Pearson Prentice Hall, Upper Saddle River, NJ

Istat (2013). Rapporto annuale

Istat (2007). La demografia d'impresa. http://www.istat.it

Jimènez G, Salas V (2006) Determinants of collateral. J Financ Econ 81:255-281

Muravyev A, Talavera O (2009) Entrepreneurs' gender and financial constraints: evidence from international data. J Comp Econ 37(2):270-286

Ogawa K, Sterken E, Tokutsu I (2010) The economics of imperfect markets, series contribution to economics. In: Calcagnini G, Saltari E (eds) Multiple bank relationships and the main bank system. Physica: Springer, Berlin, pp 73-90

Ongena S, Popov A (2013) Take care of home and family, honey, and let me take care of the money. Gender bias and credit market barriers for female entrepreneurs, Electronic copy available at: http://ssrn.com/ abstract $=2148914$

Petersen MA (2009) Estimating standard errors in finance panel data sets: comparing approaches. Rev Financ Stud 22:435-480

Pinar K-M, Norton EC, Dowd B (2011) Interaction terms in nonlinear models. Health Res Educ Trust. doi: $10.1111 / \mathrm{j} .1475-6773.2011 .01314$

Pozzolo AF (2004) The role of guarantees in bank lending. Discussion Papers, 528. Bank of Italy

Retecamere (2011) Impresa in genere, secondo rapporto nazionale sull'imprenditoria femminile

Rodano G, Serrano-Velarde NAB, Tarantino E (2011) The Causal Effect of Bankruptcy Law on the Cost of Finance. Available at SSRN: http://ssrn.com/abstract=1967485

Rosa P, Carter S (1996) Gender as a determinant of small business performance: insights from a British study. Small Bus Econ 8:463-478

Stefani ML, Vacca E (2013) Credit access for female firms: Evidence from a survey on European SMEs. Questioni di Economia e Finanza, Banca d'Italia, n.176

Storey DJ (2004) Racial and gender discrimination in the micro firms credit market? Evidence from trinidad and tobago. Small Bus Econ 23:401-422 